\title{
Efficiency Evaluation of European Countries in Terms of COVID-19
}

\author{
Avrupa Ülkelerinin COVID-19 Açısından Verimliliklerinin Değerlendirmesi \\ Gökçen BAYRAM ${ }^{1} \mathbb{1}$, Özlem YURTSEVER ${ }^{2}$ \\ ${ }^{I}$ Marmara University, Institute of Pure and Applied Sciences, Industrial Engineering, Istanbul / Turkey \\ ${ }^{2}$ Marmara University, Vocational School of Technical Sciences, Department of Property Protection and \\ Security, Istanbul / Turkey
}

\begin{abstract}
The COVID-19 Pandemic has effected millions of people all over the world. Therefore, the behaviour of countries is important to minimise the losses. In this paper the performance of 27 European countries on spread and deaths caused by COVID-19 pandemics is evaluated and compared by using input-oriented data envelopment analysis (DEA) method. The model is performed in two steps. In the first step, the contagion control efficiency is analysed whereas in the second step the medical treatment efficiency is evaluated. Moreover, the countries are classified into the four zone by using the area chart. For the countries in each zones, some recommendations are given.

Keywords: COVID-19, Data Envelopment Analysis, Contagion Control Efficiency, Medical Treatment Efficiency

Öz

COVID-19 pandemisi tüm dünyada milyonlarca insanı etkilemektedir. Bu nedenle, ülkelerin davranışları, kayıpları en aza indirmek için önemlidir. Bu araştırmada 27 Avrupa ülkesinin COVID-19 salgının neden olduğu yayılma ve ölümler üzerindeki performansı, girdi odaklı veri zarflama analizi (VZA) yöntemi kullanılarak değerlendirilmiş ve karşılaştırılmıştır. Buradak' model iki aşamada gerçekleştirilmiştir. İlk aşamada, bulaşma kontrolünün etkinliği analiz edilirken, ikinci aşamada tıbbi tedavi etkinliği değerlendirilmiştir. Ayrıca, ülkeler alan grafiği kullanılarak dört bölge de sınıflandırılmıştır. Her bölgedeki ülkeler için bazı öneriler verilmiştir.

Anahtar Kelimeler: COVID-19, Veri Zarflama Analizi, Bulaşma Kontrolünün Etkinliği, Tıbbi Tedavi Etkinliği
\end{abstract}

\section{INTRODUCTION}

A pandemic can be defined as an epidemic or a new infectious disease that spread of a large area, continent or worldwide. It can effect a substantial number of people. Throughout the course of history, there has been a number of pandemics. In Table 1, the pandemics in history are listed [1].

Table 1. Pandemics throughout the history

\begin{tabular}{|lll|}
\hline Name of Pandemic & Year & The Number of Deaths \\
\hline Plague of Athens & 430 B.C. & Nearly 100,000 \\
Antonine Plague & A.D. 165-180 & 5 million \\
Plague of Cyprian & A.D. 250-271 & 5,000 \\
Plague of Justinian & A.D. 541-542 & $30-50$ million \\
Japanese Smallpox Epidemic & A.D. $735-737$ & 1 million \\
The Black Death & $1346-1353$ & 200 million \\
Smallpox & 1520 & 56 million \\
Cocoliztli Epidemic & $1545-1548$ & 15 million \\
Great Plague of London & $17^{\text {th }}$ Century & 3 million \\
Great Plague of Marseille & $18^{\text {th }}$ Century & 600,000 \\
Russian Plague & $1770-1772$ & 100,000 \\
Philadelphia Yellow Fever Epidemic & 1793 & 5,000 \\
Cholera Epidemic & $1817-1923$ & 1 million \\
Plague & 1855 & 12 million \\
Flu Pandemic & $1889-1890$ & 1 million \\
American Polio Epidemic & 1916 & 6,000 \\
Spanish Flu & $1918-1920$ & $40-50$ million \\
Asian Flu & $1957-1958$ & 1,1 million \\
Hong Kong Flu & $1968-1970$ & 1 million \\
AIDS Pandemic and Epidemic & $1981-$ present day & $25-35$ million \\
SARS Pandemic & $2002-2003$ & 770,000 \\
H1N1 Swine Flu Pandemic & $2009-2010$ & 200,000 \\
MERS Pandemic & $2012-$ present day & 850,000 \\
Ebola Epidemic & $2014-2016$ & 11,300 \\
COVID-19 & $2019-$ present day & 400,000 (still continues) \\
\hline
\end{tabular}

Corresponding Author: Özlem YURTSEVER, Tel: 021677740 79, e-posta: ozlem.yurtsever@marmara.edu.tr 
The novel coronavirus, which is also known as COVID-19, was detected for the first time in China in December 2019. Afterwards, the virus have spread to almost all of the countries. Globally there are more than 8 million confirmed cases and over 400,000 death cases by June 18, 2020 [2]. Total case distribution of the regions are given in Figure 1.

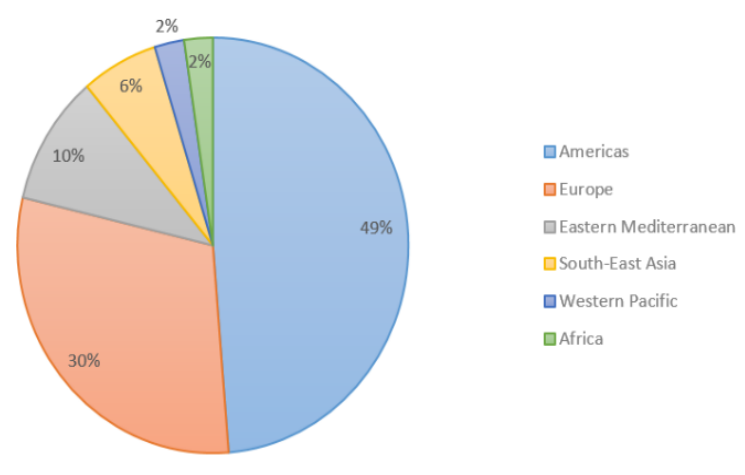

Figure 1. Share of total confirmed cases

COVID-19 has infected a tremendously larger population around the world and has many more death cases compared to previously well-known coronaviruses such as SERS or MERS [3]. The number of confirmed and death cases in a country and the increase/decrease rate depend profoundly on the readiness and the conditions of a country. Since COVID-19 become a focus issue for everyone, the studies on this disease are conducted with different perspectives [4, 5, 6, 7, 8 and 9]. In one study, authors have compared 19 selected countries in two dimensions by using dynamic data envelopment analysis. For the two analysis, population, population density and age 65 and above were the inputs where, the first output was COVID-19 virus confirmed cases and the second output was COVID-19 virus confirmed deaths. By using the first model, the objective was to compare the countries on controlling the prevalence of COVID-19, the objective of the second model was preventing the mortality caused by of COVID-19 [10]. In another study, authors have compared and classified 29 countries by using DEA model in two steps. In the first step, population density and average of 13 International Health Regulations Core Capacity Scores (IHRCC) were considered as inputs whereas the confirmed cases were outputs. In the second part of their model, confirmed cases were considered as input whereas the death and recovered cases were chosen as outputs. As a result, Singapore, Vietnam, and Belgium were the countries with the highest efficient in both models [11]. The same authors have performed another DEA model among with 30 countries by using the two weeks data. In this study, as input they considered days since the first confirmed case and population density, and as an output average contagion rate is chosen [12].

In this study, the effectiveness of the countries in dealing with the COVID-19 pandemic is analysed by using the DEA model. Apart from the literature mentioned above, the DEA model is conducted in two stages. In the first stage, the effect of population and health security capabilities of the countries are questioned on confirmed cases. Later on, the death cases are analyzed according to the confirmed cases, hospital beds and 65 ages and over population of the countries. In order to find out the health security capabilities of the countries, Global Health Security (Index) is used. GHS Index, which covers global health security capabilities in 195 countries, is developed between the Nuclear Threat Initiative, Johns Hopkins Center for Health Security, and the Economist Intelligence Unit. GHS Index prioritizes countries' capacities as well as existence of functional, tested, proven capabilities for stopping outbreaks at the source by using 140 questions. These questions are categorized into six categories with 34 indicators as shown in the Table 2.

The scores are normalized between 0 and 100, where 100 is the most favorable. According to the index, there are three tiers. Countries that score between 0 and 33.3 are in the bottom tier, between 33.4 and 66.6 are in the middle tier, and between 66.7 and 100 are in the upper or "top" tier. The GHS Index ranks the countries that are best prepared for an epidemic or pandemic. According the 2019 report, among all of the 195 countries, none of them is fully prepared for the epidemics or pandemics [13]. According to the Index, for the year 2019, the top 10 country over the world is given in Table 3 .

The COVID-19 Pandemic has effected millions of people all over the world. Therefore the behavior of the countries are important to minimize the losses. Since COVID-19 become a focus issue for everyone, the studies on this disease are conducted with different perspectives. The aim of this study is to evaluate and compare the performance of 27 European Countries on spread and deaths caused by COVID-19 pandemics by using input-oriented data envelopment analysis (DEA) method. Moreover, the countries are classified into the four zone by using the area chart. For the countries in each zones, some recommendations are given.

The construction of the paper is as follows. In the next section, the methodology is explained as well as the data definition and selection. Section 3 presents the results of the applied model with the several analyses. Finally, Section 4 concludes this paper. 
Table 2. GHS index categories

\begin{tabular}{|c|c|c|}
\hline Category & Explanation & Indicators \\
\hline Prevent & $\begin{array}{l}\text { Preventing the } \\
\text { emergence or release } \\
\text { of pathogens }\end{array}$ & $\begin{array}{l}\text { 1.1) Antimicrobial resistance (AMR) } \\
\text { 1.2) Zoonotic disease } \\
\text { 1.3) Biosecurity } \\
\text { 1.4) Biosafety } \\
\text { 1.5) Dual use research and culture of responsible science } \\
\text { 1.6) Immunisation }\end{array}$ \\
\hline Detect & $\begin{array}{l}\text { Early detection and } \\
\text { reporting epidemic of } \\
\text { potential } \\
\text { international concern }\end{array}$ & $\begin{array}{l}\text { 2.1) Laboratory systems } \\
\text { 2.2) Real time surveillance and reporting } \\
\text { 2.3) Epidemiology workforce } \\
\text { 2.4) Data integration between human/animal/environmental health } \\
\text { sectors }\end{array}$ \\
\hline Respond & $\begin{array}{l}\text { Rapidly responding } \\
\text { to and mitigating the } \\
\text { spread of an epidemic }\end{array}$ & $\begin{array}{l}\text { 3.1) Emergency preparedness and response planning } \\
\text { 3.2) Exercising response plans } \\
\text { 3.3) Emergency response operation } \\
\text { 3.4) Linking public health and security authorities } \\
\text { 3.5) Risk communication } \\
\text { 3.6) Access to communications infrastructure } \\
\text { 3.7) Trade and travel restrictions }\end{array}$ \\
\hline Health & $\begin{array}{l}\text { Sufficient and robust } \\
\text { health sector to treat } \\
\text { the sick and protect } \\
\text { health workers }\end{array}$ & $\begin{array}{l}\text { 4.1) Health capacity in clinics, hospitals and community care centres } \\
\text { 4.2) Medical countermeasures and personnel deployment } \\
\text { 4.3) Healthcare access } \\
\text { 4.4) Communications with healthcare workers during a public health } \\
\text { emergency } \\
\text { 4.5) Infection control practices and availability of equipment } \\
\text { 4.6) Capacity to test and approve new medical countermeasures }\end{array}$ \\
\hline Norms & $\begin{array}{l}\text { Commitments to } \\
\text { improving national } \\
\text { capacity, financing } \\
\text { and adherence to } \\
\text { norms }\end{array}$ & $\begin{array}{l}\text { 5.1) International Health Regulations (IHR) reporting compliance and } \\
\text { disaster risk reduction } \\
\text { 5.2) Cross-border agreements on public health emergency response } \\
\text { 5.3) International commitments } \\
\text { 5.4) JEE and PVS } \\
\text { 5.5) Financing } \\
\text { 5.6) Commitment to sharing of genetic \& biological data \& specimens }\end{array}$ \\
\hline Risk & $\begin{array}{l}\text { Risk environment } \\
\text { and vulnerability to } \\
\text { biological threats }\end{array}$ & $\begin{array}{l}\text { 6.1) Political and security risk } \\
\text { 6.2) Socio-economic resilience } \\
\text { 6.3) Infrastructure adequacy } \\
\text { 6.4) Environmental risks } \\
\text { 6.5) Public health vulnerabilities }\end{array}$ \\
\hline
\end{tabular}

Table 3. Top ten countries according to GHS index, 2019

\begin{tabular}{|rlr|}
\hline Rank & Country & Score/100 \\
\hline 1 & United States & 83.5 \\
2 & United Kingdom & 77.9 \\
3 & Netherlands & 75.6 \\
4 & Australia & 75.5 \\
5 & Canada & 75.3 \\
6 & Thailand & 73.2 \\
7 & Sweden & 72.1 \\
8 & Denmark & 70.4 \\
9 & South Korea & 70.2 \\
10 & Finland & 68.7 \\
\hline
\end{tabular}

\section{MATERIAL AND METHOD}

The performance of the countries dealing with the COVID-19 pandemics is analysed. The novel disease is appeared rapidly and the countries faced to deal with this uncertain conditions. Thus, the research is still young about this disease. Inorder to choose the method, a brief literature survey is conducted. In healthcare system, DEA method is frequently used in the literature to measure the efficiency [14, 15, 16, 17, 18 and 19]. In this study, to analyse the effectiveness of the countries dealing the COVID-19 pandemics, the DEA method is chosen for two reasons. Bu using the DEA method, efficiency is measured by comparing the best application instead of the average. Additionally, unlike from the other parametric methods, DEA does not necessitate as much data [10].

DEA is a linear programming method planned to measure the relative efficiencies of a set of Decision Making Units (DMU) such as hospitals, education, 
manufacturing sector and banking sector with multiple inputs and multiple outputs [20]. In addition, DEA which is a data oriented method is used to compare and sort the efficiency of DMUs [21].

DEA is materialized as the assumption of constant returns to scale based on Charnes, Cooper, Rhodes (CCR). The CCR model can be input or output oriented. In an input orientation, for a certain level of output, DEA minimizes the input which shows how much an institution can decrease its input for a particular output. In an output orientation, for a certain level of input, DEA maximizes the output which shows how much an institution can increase its output for a particular input [22]. The controllability of inputs and outputs is the main factor on deciding the main theme of the model [23]. In other words, if the decision maker has an audit on input, the model is input oriented whereas, if the decision maker has an audit on output, the model is output oriented. In health sector, for the decision makers it is generally hard to control the outputs however they have the authority to control the inputs.

The CCR model, is a fractional linear programming problem and can be transformed into an equivalent linear program. Thus, the CCR with an input oriented model can be formulated as the following [24]:

$$
\begin{array}{ll}
\underset{\mu_{k}, v_{\mathrm{i}}}{\operatorname{Maximize}} & \sum_{k=1}^{p} \mu_{k} y_{k o} \\
\text { Subject to } & \sum_{i=1}^{m} v_{\mathrm{i}} \chi_{\mathrm{io}}=1, \\
& \sum_{k=1}^{p} \mu_{k} y_{k j}-\sum_{i=1}^{m} v_{\mathrm{i}} \chi_{i j} \leq 0, \mathrm{j}=1, \ldots, \mathrm{n}, \\
\mu_{k} \geq \varepsilon, \quad v_{\mathrm{i}} \geq \varepsilon, \quad \mathrm{k}=1, \ldots, \mathrm{p} ; \mathrm{i}=1, \ldots, \mathrm{m} .
\end{array}
$$

This study designed as three steps based on DEA:

1. Definition and selection of DMUs: Since the countries are compared, they are considered as the DMUs. The critical situation in Europe led the study based on the European countries which are listed in the data selection part.

2. Detection the variables of inputs and outputs: DEA does not perform adequate results when the number of inputs or outputs are large. Consequently, this study is executed in two steps. In the first step as shown in Figure 2, GHS Index of a country is taken as input whereas the ratio of confirmed cases to the population is output. Thus the performance ratio analysis (efficiency=output/input) of the countries are considered. In the second step, DEA model is used, where the output is the ratio of death cases over confirmed cases where hospital beds and 65 ages\&over population are inputs as shown in Figure 3.

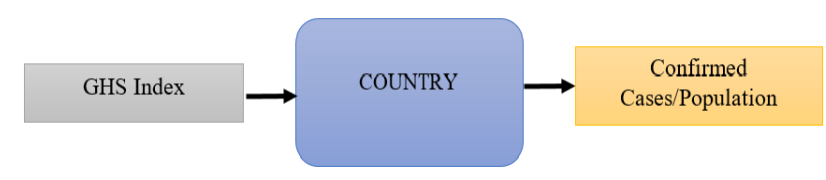

Figure 2. The first step of the performance ratio analysis model

It should be noted that the ratio of confirmed cases to the population is an undesirable output. A solution to the first step of this model gives the Contagion Inefficiency for each country.

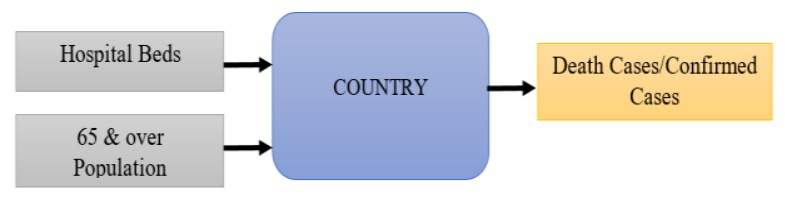

Figure 3. The second step of the DEA model

It should be noted that Population ages 65 and above (\% of total population) is an undesirable input and the ratio of death cases to the confirmed cases is an undesirable output. If the death rate is the most efficient for a country, then that country is the worst, thus the death rate is considered as an undesired output in this manner. A solution to this model gives the Medical Treatment Efficiency for each country.

3. Implementation of the model and evaluation of the results: In the final part of the study, the conditions of the countries regarding the confirmed cases and death cases are discussed.

Due to the lack of testing capacity, a large proportion of the suspected cases may not be not tested. Thus, it should be noted that "confirmed cases" differ than "actual cases".

In one study, Shirouyehzad and his friends have compared and classified 29 countries by using DEA model as mentioned before. They have classified the countries by using the chart area [11]. In this paper, similar to the mentioned paper, European Countries are classified as shown in Figure 4. The horizontal axis and vertical axis represent the medical treatment efficiency and contagion inefficiency, respectively. The total mean values of the DEA result will be used to divide the chart into four areas.

The countries are placed in the chart according to their DEA results in the first and second step. The description of the areas is given as in Table 4. 


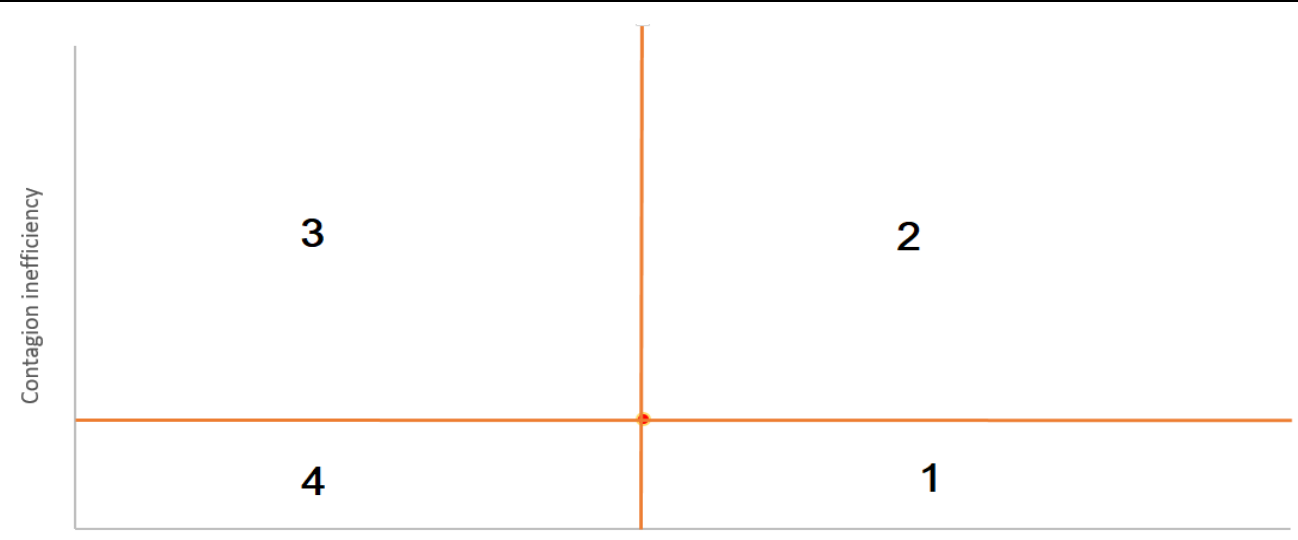

Medical Treatment Efficiency

Figure 4. Classification area of European counties

Table 4. Description of the country classification

\begin{tabular}{|cr|}
\hline Area & Description \\
\hline 1 & Good performance both in contagion spread and efficiency in medical treatment \\
2 & Good performance in medical treatment but poor performance in spread of contagion \\
3 & Poor performance both in contagion spread and efficiency in medical treatment \\
4 & Poor performance in medical treatment but good performance in spread of contagion
\end{tabular}

In order to get a meaningful analysis, suitable inputs and outputs must be selected. The selection of factors that design the model and analyzed process is the most important task [18]. In this study the CCR model that depends on constant returns to scale, is used as input oriented method.

In literature there are two explanations about the sufficient number of DMUs [25]:

I. When, $m$ is the number of inputs and $p$ is the number of outputs, the number of DMUs $(\mathrm{N})$ should be at least one more than the total of inputs and outputs as shown in the Equation 1.

$$
N \geq m+p+1
$$

II. When, $\mathrm{m}$ is the number of inputs and $\mathrm{p}$ is the number of outputs, the number of DMUs must be at least two times of the sum of total number of inputs and outputs as show in the Equation 2.

$$
N \geq 2 \times(m+p)
$$

Due to the data limitation, 27 European countries were selected for which information on COVID-19, hospital beds, population and GHS Index is available. The selected countries are Austria, Bulgaria, Croatia, Cyprus, Czech Republic, Denmark, Estonia, Finland, France, Germany, Greece, Hungary, Iceland, Italy, Luxembourg, Malta, Montenegro, Netherlands, North Macedonia, Norway, Poland, Portugal, Romania, Slovakia, Spain, Switzerland and Turkey. The year and source of the data used for this study is summarized as in Table 5.

Table 5. Summary of the data used in DEA

\begin{tabular}{|ccc|}
\hline Data Description & Data Source & Year \\
\hline Cumulative cases of COVID19 & World Health Organization (WHO) & 2020 (latest data is on June 18) \\
\hline $\begin{array}{c}\text { Cumulative deaths from COVID19 } \\
\text { Population of the countries }\end{array}$ & World Health Organization (WHO) & 2020 (latest data is on June 18) \\
\hline $\begin{array}{c}\text { Population ages 65 and above (\% of total } \\
\text { population) }\end{array}$ & Worldbank & 2018 \\
\hline Available hospital beds & Worldbank & 2018 \\
\hline GHS index values & EUROSTAT & 2017 \\
\hline
\end{tabular}




\section{FINDINGS AND DISCUSSIONS}

Since the number of hospital beds will vary depending on the country population, the number of hospital beds per thousand people is used as the input variable. In this study, the measurement of the effectiveness of decision units (countries) was carried out with the DEAP 2.1 program. The effectiveness of European countries on spread and deaths caused by COVID-19 pandemics is evaluated by using input-oriented DEA model. In health industry, the power of countries to control and change output is limited. Countries can make changes in inputs to carry out more effective policies. Thus, they can achieve the goals they want to reach in the output. In addition to the input-oriented method, the CCR model was used in this study.

In this study, data envelopment analysis compares the countries to identify the causes of ineffectiveness in countries' health systems. Therefore, it is not possible to conclude that the countries which are effective, are the countries with the best health system. However, it can be said that they have relatively effective health systems compared to the existing decision units in the model.
In this paper, the model is conducted in two steps to compare the 27 European countries in terms of COVID-19. In the first step, to find out the contagion control efficiency, GHS Index of a country is taken as input whereas the ratio of confirmed cases to the population is output. In the second step, to find out the medical treatment efficiency, hospital beds and 65 ages\&over population are taken as inputs whereas the ratio of death cases over confirmed cases is output. The first step efficiency column represents the contagion control inefficiency in comparison to other countries. In the first step efficiency column, the value 1 indicates that the related country has had poor performance in contagion control of COVID-19 according to the GHS Index and the number of confirmed cases to population. The results of the DEA analysis are demonstrated in Table 6.

According to the results, Luxemburg has an efficiency value of 1 showing that it has a poor performance in contagion control. In addition, Denmark and Iceland have an efficiency value of 1 showing that these countries have had good performance in medical treatment of COVID-19 patients in comparison to other countries in the study.

Table 6. The Efficiency Values of the Steps

\begin{tabular}{|c|c|c|c|c|c|c|c|}
\hline \multirow[b]{2}{*}{ No } & \multirow[b]{2}{*}{ Country } & $\begin{array}{ll}1^{\text {st }} & \text { Step }\end{array}$ & $2^{\text {nd }} \quad$ Step & \multirow[b]{2}{*}{ No } & \multirow[b]{2}{*}{ Country } & \multirow[b]{2}{*}{$\begin{array}{l}\mathbf{1}^{\text {st }} \quad \text { Step } \\
\text { Efficiency } \\
\text { Contagion } \\
\text { Control } \\
\text { Inefficiency }\end{array}$} & \multirow[b]{2}{*}{$\begin{array}{l}\mathbf{2}^{\text {nd }} \quad \text { Step } \\
\text { Efficiency } \\
\text { Medical } \\
\text { Treatment } \\
\text { Efficiency }\end{array}$} \\
\hline & & $\begin{array}{l}\text { Efficiency } \\
\text { Contagion } \\
\text { Control } \\
\text { Inefficiency }\end{array}$ & $\begin{array}{l}\text { Efficiency } \\
\text { Medical } \\
\text { Treatment } \\
\text { Efficiency }\end{array}$ & & & & \\
\hline 1 & Austria & 0.212 & 0.476 & 15 & Luxembourg & 1 & 0.555 \\
\hline 2 & Bulgaria & 0.072 & 0.496 & 16 & Malta & 0.245 & 0.901 \\
\hline 3 & Croatia & 0.074 & 0.622 & 17 & Montenegro & 0.075 & 0.680 \\
\hline 4 & Cyprus & 0.122 & 0.745 & 18 & Netherlands & 0.242 & 0.761 \\
\hline 5 & Czechia & 0.126 & 0.548 & 19 & North Macedonia & 0.351 & 0.505 \\
\hline 6 & Denmark & 0.195 & 1 & 20 & Norway & 0.162 & 0.815 \\
\hline 7 & Estonia & 0.172 & 0.727 & 22 & Poland & 0.094 & 0.474 \\
\hline 8 & Finland & 0.124 & 0.971 & 22 & Portugal & 0.390 & 0.995 \\
\hline 9 & France & 0.220 & 0.441 & 23 & Romania & 0.171 & 0.439 \\
\hline 10 & Germany & 0.228 & 0.488 & 24 & Slovakia & 0.041 & 0.533 \\
\hline 11 & Greece & 0.036 & 0.754 & 25 & Spain & 0.516 & 0.858 \\
\hline 12 & Hungary & 0.048 & 0.359 & 26 & Switzerland & 0.351 & 0.634 \\
\hline 13 & Iceland & 0.720 & 1 & 27 & Turkey & 0.274 & 0.495 \\
\hline 14 & Italy & 0.454 & 0.942 & Ave & age & 0.249 & 0.675 \\
\hline
\end{tabular}




\section{CONCLUSION AND RECOMMENDATIONS}

In this study, European countries are analysed and compared in two steps in the context of COVID-19 pandemics. In the first step, GHS Index was taken as input and the ratio of confirmed cases over population was taken as output. Data Envelopment Analysis shows the active countries as the value 1 . However, the value 1 for the ratio of confirmed cases over population means that these countries are very active to spread the COVID-19 which is an undesirable output. In the analysis the countries that have value 1 are accepted as ineffective countries.

The values in Table 6, are used to create the four areas depicted in Figure 5. In this figure, the average efficiency for the first step, 0.249 , and for the second step, 0.675, are used to divide the chart into four areas. According to these areas, the countries are classified in to the four group to analyze their efficiencies.

From Figure 5, it can be seen that Malta, Montenegro, Cyprus, Denmark, Estonia, Finland, Greece, Netherlands and Norway are in Area 1, showing that these countries have been acted efficiently both in contagion control and medical treatment of the patients. After all, Malta lies on the border is considered in the first area since its contagion control inefficiency value, 0.245 , is slightly below to the average value of all the countries, 0.249. Italy, Spain, Iceland and Portugal are in Area 2. These countries have had good performance in medical treatment but they have had controlled the contagion inefficiently. The countries which have been acted inefficiently both in contagion control and medical treatment of the patients are in Area 3. Luxembourg, North Macedonia, Switzerland and Turkey are in critical conditions in this manner. Lastly, Poland, Romania, Slovakia, Austria, Bulgaria, Czechia, Hungary, France, Germany and Crotia are in Area 4. These countries have been successful in providing a good performance in contagion control but they have had poor performance in medical treatment.
According to the classification of areas in Figure 5, Montenegro, Netherlands, Malta, Germany, France and Austria need to pay a special attention to maintain their current performance.

Montenegro is in the first area which is the best performance area. However, if Montenegro acts as Hungary in terms of medical treatment efficiency, then the performance area will change to the fourth zone. Since the average value of step 2 analysis is 0.675 and the value for Hungary is 0.359 , it means that Hungary is the worst country in terms of medical treatment efficiency. Thus, Montenegro needs to be careful in keeping its medical treatment capability as it is.

The contagion control inefficiency value of Netherlands and Malta are 0.242 and 0.245, respectively. These values are very close to the average value of 0.249 . The countries with the values below 0.249 are efficient whereas the others are inefficient. Inefficiency increases as it approaches to the value of 1. The most inefficient country of step 1 analysis is Luxemburg. If Netherlands and Malta behave like Luxemburg, then their zone will change from 1 to 2 . Thus they will be one of the contagion control inefficient countries.

Germany, France and Austria are in the fourth zone. In this zone they are already inefficient in terms of medical treatment. However they are trying to control their contagion efficiently. Like Netherlands and Malta, if these countries act like Luxemburg their zone will downgrade to the third area which is the worst case.

On the other hand, the average value of contagion control inefficiency is 0.249 whereas Turkey's value is 0.274 . Turkey which is on the third area, can easily go up to the fourth area with a little effort by controlling the contagion efficiently like Greece and Slovakia.

In summary, the countries are classified in to the four zones according to their performance in this manner. The classification of the countries and the conclusion about these countries are given in Table 7.

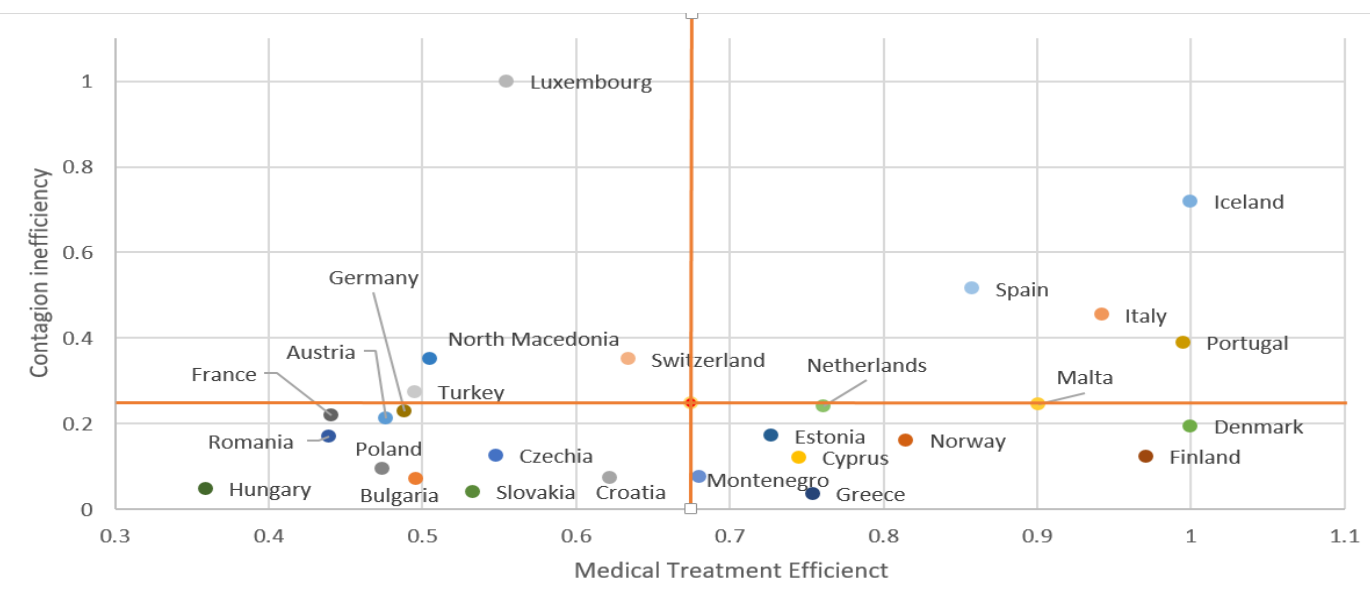

Figure 5. The area chart for classification of the European countries 
Table 7. Classification of the countries

\begin{tabular}{|c|c|c|}
\hline Area & Countries & Conclusion \\
\hline 1 & $\begin{array}{l}\text { Malta, Montenegro, Cyprus, Denmark, Estonia, } \\
\text { Finland, Greece, Netherlands, Norway }\end{array}$ & High performance \\
\hline 2 & Italy, Spain, Iceland, Portugal & $\begin{array}{l}\text { Average performance, needs to learn contagion } \\
\text { control as in the countries in the area } 1 \text { and } 4\end{array}$ \\
\hline 3 & Luxembourg, North Macedonia, Switzerland, Turkey & In critical conditions \\
\hline 4 & $\begin{array}{l}\text { Poland, Romania, Slovakia, Austria, Bulgaria, } \\
\text { Czechia, Hungary, France, Germany, Crotia }\end{array}$ & $\begin{array}{l}\text { Average performance, needs to learn medical } \\
\text { treatment as in the countries in the area } 1 \text { and } 2\end{array}$ \\
\hline
\end{tabular}

According to Table 7, Malta, Montenegro, Cyprus, Denmark, Estonia, Finland, Greece, Netherlands, and Norway are the countries with high performance both in contagion control and medical treatment. Thus all the other countries should take these countries as an example. However, Luxembourg, North Macedonia, Switzerland and Turkey are in critical conditions and need a special attention.

If the bed numbers in hospitals are low, then it means that, because of the low capacity the patients cannot be treated fully leading the higher number of death ratios. If the number of beds in hospitals is high, patients diagnosed with COVID-19 can be quarantined in hospitals, the possibility of spread is reduced, and mortality rates can be reduced with rapid treatment. In addition, it is known that the possibility of death from COVID-19 for elderly people (65+) and people with chronic diseases are high then the others. Thus, if the population of elderly people $(65+)$ is relatively low then it is expected the death rates being low.

The world map shown in Figure 6 gives the biref visual summary of the related countries according to this study's classification.

According to this research study's model, the regions 4 and 2 are opposite of each other both in the sense of medical treatment and contagion inefficiency. One of the reasons can be the healthcare system model. The healthcare system of all countries in the $4^{\text {th }}$ region has the similar social security system. Predominant source of financing for public health expenditure is social security system which is by mandatory fees paid by employers and workers or through taxes. On the other hand, all countries in the $2^{\text {nd }}$ region has the similar system such as major source of financing for public health expenditure is taxes.

The indicators chosen can affect the results of the model easily. Therefore, different inputs and outputs can change the results and analysis. These indicators can be more comprehensive in further studies for extended results. Furthermore, as a future work, the factors such as social distancing, lockdown measures or population density can be added to the model to find the efficiencies of the countries which are used in this study.

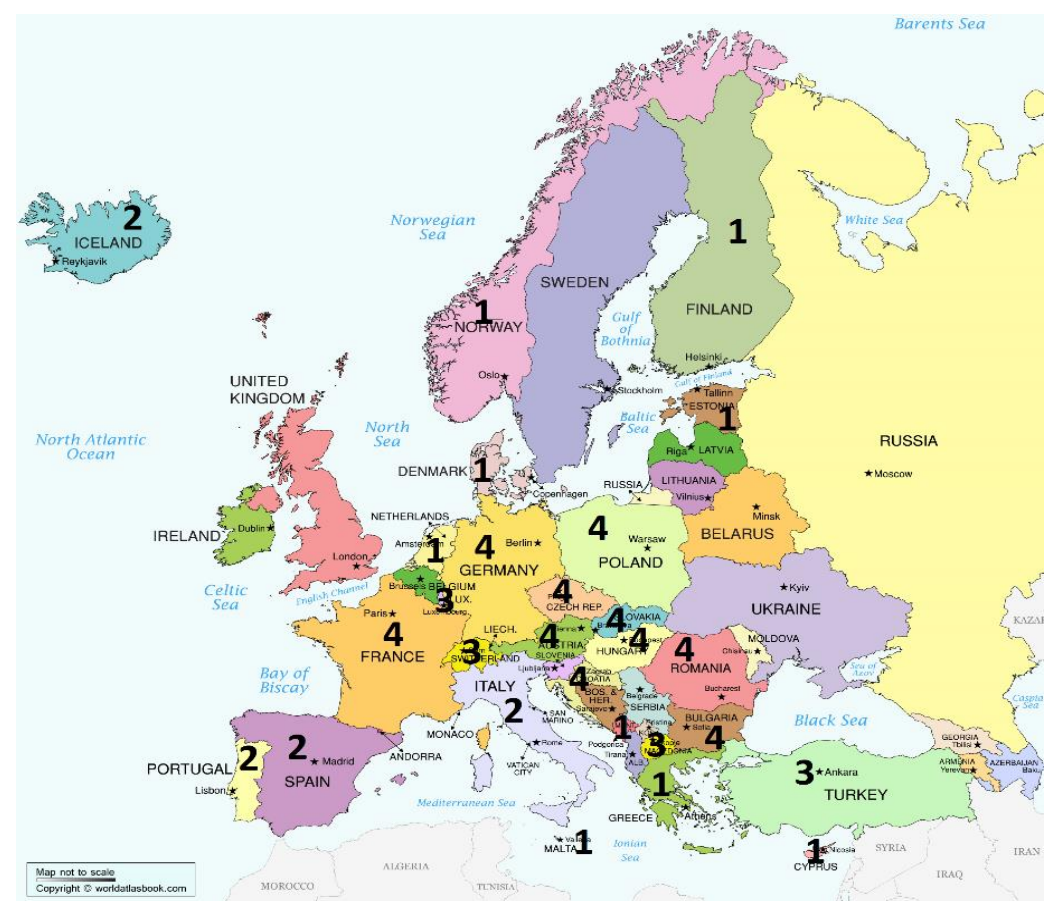

Figure 6. The visual summary of this study 


\section{REFERENCES}

[1] LePan, N., (2020). Visualizing the History of Pandemics. Visual Capitalist. https://www.visualcapitalist.com/history-ofpandemics-deadliest. (accessed Jul. 05, 2020).

[2] WHO. (2020). Coronavirus disease (COVID-19). https://www.who.int/emergencies/diseases/novel -coronavirus-2019 (accessed Jun. 18, 2020).

[3] Jouzdani, J., \& Shirouyehzad, H. (2020). Fight against COVID-19: What can be done in the case of Iran? Journal of Applied Research on Industrial Engineering, $\quad 7(1), \quad 1-12$. https://doi.org/10.22105/jarie.2020.223981.1145

[4] Berman, J. D., \& Ebisu, K. (2020). Changes in U.S. air pollution during the COVID-19 pandemic. Science of The Total Environment, 739,

139864 https://doi.org/10.1016/j.scitotenv.2020.139864

[5] Adekunle, I. A., Onanuga, A. T., Akinola, O. O., \& Ogunbanjo, O. W. (2020). Modelling spatial variations of coronavirus disease (COVID-19) in Africa. Science of The Total Environment, 729, 138998.

https://doi.org/10.1016/j.scitotenv.2020.138998

[6] Wu, Y., Jing, W., Liu, J., Ma, Q., Yuan, J., Wang, Y., Du, M., \& Liu, M. (2020). Effects of temperature and humidity on the daily new cases and new deaths of COVID-19 in 166 countries. Science of The Total Environment, 729, 139051. https://doi.org/10.1016/j.scitotenv.2020.139051

[7] Thu, T. P. B., Ngoc, P. N. H., Hai, N. M., \& Tuan, L. A. (2020). Effect of the social distancing measures on the spread of COVID-19 in 10 highly infected countries. Science of The Total Environment, $\quad 742, \quad 140430$. https://doi.org/10.1016/j.scitotenv.2020.140430

[8] Oksanen, A., Kaakinen, M., Latikka, R., Savolainen, I., Savela, N., \& Koivula, A. (2020). Regulation and Trust: 3-Month Follow-up Study on COVID-19 Mortality in 25 European Countries. JMIR Public Health and Surveillance, 6(2), e19218. https://doi.org/10.2196/19218

[9] Singh, R. K., Rani, M., Bhagavathula, A. S., Sah, R., Rodriguez-Morales, A. J., Kalita, H., Nanda, C., Sharma, S., Sharma, Y. D., Rabaan, A. A., Rahmani, J., \& Kumar, P. (2020). Prediction of the COVID-19 Pandemic for the Top 15 Affected Countries: Advanced Autoregressive Integrated Moving Average (ARIMA) Model. JMIR Public Health and Surveillance, 6(2), e19115. https://doi.org/10.2196/19115

[10] Ghasemi, A., Boroumand, Y., \& Shirazi, M. (2020). How do governments perform in facing COVID-19? Munich Personal RePEc Archive, Apr. 15, 2020, Accessed: Jul. 05, 2020. [Online]. Available: https://mpra.ub.unimuenchen.de/99844/.

[11] Shirouyehzad, H., Jouzdani, J., \& Khodadadi Karimvand, M. (2020). Fight against COVID-19: A global efficiency evaluation based on contagion control and medical treatment. Journal of Applied Research on Industrial Engineering, 7(2), 109120.

https://doi.org/10.22105/jarie.2020.225087.1146

[12] Shirouyehzad, H., Jouzdani, J., \& KhodadadiKarimvand, M. (2020). An Analysis of the COVID-19 Contagion Growth in European Countries. Iranian Journal of Optimization, 12(1), 11-19.

[13] Cameron, E. E., Nuzzo, J. B., \& Bell, J. A. (2019). Global health security index: Building collective action and accountability. Nuclear Threat Initiative and Johns Hopkins Bloomberg School of Public Health.

[14] Popescu, C., Asandului, L., \& Fatulescu, P. (2014). A Data Envelopment Analysis for Evaluating Romania's Health System. Procedia Social and Behavioral Sciences, 109, 1185-1189. https://doi.org/10.1016/j.sbspro.2013.12.609

[15] Stefko, R., Gavurova, B., \& Kocisova, K. (2018). Healthcare efficiency assessment using DEA analysis in the Slovak Republic. Health Economics Review, 8(1), 1-12.

[16] Ozcan, Y. A. (2008). Health Care Benchmarking and Performance Evaluation: An Assessment using Data Envelopment Analysis (DEA). Springer US. https://doi.org/10.1007/978-0-38775448-2

[17] Kaya Samut, P., \& Cafr1, R. (2016). Analysis of the Efficiency Determinants of Health Systems in OECD Countries by DEA and Panel Tobit. Social Indicators Research, 129(1), 113-132. https://doi.org/10.1007/s11205-015-1094-3

[18] Kohl, S., Schoenfelder, J., Fügener, A., \& Brunner, J. O. (2019). The use of Data Envelopment Analysis (DEA) in healthcare with a focus on hospitals. Health Care Management Science, 22(2), 245-286. https://doi.org/10.1007/s10729-018-9436-8

[19] Azadi, M., \& Farzipoor Saen, R. (2013). A combination of QFD and imprecise DEA with enhanced Russell graph measure: A case study in healthcare. Socio-Economic Planning Sciences, 47(4), 281-291. https://doi.org/10.1016/j.seps.2013.05.001

[20] Tlotlego, N., Nonvignon, J., Sambo, L. G., Asbu, E. Z., \& Kirigia, J. M. (2010). Assessment of productivity of hospitals in Botswana: A DEA application. International Archives of Medicine, 3, 27. https://doi.org/10.1186/1755-7682-3-27

[21] Morita, H., \& Avkiran, N. K. (2009). Selecting inputs and outputs in data envelopment analysis by designing statistical experiments. Journal of the Operations Research Society of Japan, 52(2), 163-173. https://doi.org/10.15807/jorsj.52.163

[22] Huguenin, J.-M. (2012). Data envelopment analysis (DEA): A pedagogical guide for decision makers in the public sector. IDHEAP.

[23] Ray, S. C. (2004). Data Envelopment Analysis: Theory and Techniques for Economics and 
Operations Research (1st ed.). Cambridge University

Press. https://doi.org/10.1017/CBO9780511606731

[24] Yun, Y. B., Nakayama, H., \& Tanino, T. (2004). A generalized model for data envelopment analysis. European Journal of Operational Research, 157(1), 87-105.
[25] Boussofiane, A., Dyson, R. G., \& Thanassoulis, E. (1991). Applied data envelopment analysis. European Journal of Operational Research, 52(1), $1-15$. https://doi.org/10.1016/0377- 